\title{
Vitamin D and Cardiovascular Disease
}

\author{
Jacqueline S. Danik, MD, DrPH ${ }^{\star}$ and JoAnn E. Manson, MD, DrPH \\ Division of Preventive Medicine, Brigham and Women's Hospital Harvard Medical School
}

\section{OPINION}

Vitamin D has received widespread attention for its potential role in preventing cardiovascular disease (CVD) and type 2 diabetes mellitus. Several epidemiological studies have suggested that individuals with low blood levels of vitamin D have increased risks of heart disease, stroke, hypertension, and diabetes. Yet the revised 2011 Institute of Medicine report for intake of calcium and vitamin $\mathrm{D}$, which was guided by skeletal health alone, concluded that the evidence that vitamin D prevents CVD, diabetes, or other cardiometabolic outcomes was inconsistent and inconclusive and did not meet criteria for establishing a cause and effect relationship. ${ }^{1,2}$ This finding was consistent with an earlier systematic review conducted by the Agency for Healthcare Research and Quality (AHRQ) in 2009. ${ }^{3}$ Ongoing clinical trials seek to address the effects of vitamin D supplementation on CVD and other nonskeletal outcomes.

\section{VITAMIN D LEVELS IN US, PREVALENCE OF VITAMIN D DEFICIENCY AND CURRENT DIETARY GUIDELINES}

Based on bone health, recommended dietary allowances (covering requirements of $\geq 97.5 \%$ of the population) for vitamin D are $600 \mathrm{IU} / \mathrm{d}$ for individuals aged 1 to 70 years and $800 \mathrm{IU} /$ $\mathrm{d}$ for those older than 70 years, corresponding to a serum 25-hydroxyvitamin $\mathrm{D}$ level of 20 $\mathrm{ng} / \mathrm{mL}$ or greater $\left(250 \mathrm{nmol} / \mathrm{L}\right.$ ) under conditions of minimal sun exposure. ${ }^{2}$

Vitamin D is synthesized in the skin as a pro-hormone in response to ultraviolet light and is also absorbed from the gastrointestinal tract. Both sources are activated in the liver to $25(\mathrm{OH}) \mathrm{D}$ and in the kidney to 1,25 -dihydroxyvitamin $\mathrm{D}\left[1,25(\mathrm{OH})_{2} \mathrm{D}\right]$; the $25(\mathrm{OH}) \mathrm{D}$ level has a half-life of 2-3 weeks and is a measure of vitamin D status. ${ }^{4}$ Extra-renal activation of vitamin $\mathrm{D}$ occurs in a number of tissues which may affect inflammation and innate immunity. ${ }^{5-9}$ The National Health and Nutrition Examination Survey (NHANES) indicated that vitamin D "insufficiency" exists in more than half of US middle-aged and older women ${ }^{10}$ and more than a third of similarly aged men, ${ }^{5,11}$ although there has been recent debate about what constitutes vitamin D deficiency and sufficiency. ${ }^{12}$

Despite lack of consensus on the definition and prevalence of vitamin D insufficiency in the United States ${ }^{1,2}$, some estimates suggest nonetheless that at least one third of middle-aged and older Americans have such insufficiency ${ }^{5,13}$. The elderly are particularly vulnerable, at least in part due to reduced physical and outdoor activity. ${ }^{14-19}$ African-American individuals are also particularly vulnerable, in part because darkly pigmented skin is less able to synthesize vitamin $\mathrm{D}$ in response to solar radiation and because blacks tend to have

\footnotetext{
"Corresponding author: Address: Division of Preventive Medicine, Brigham and Women's Hospital, 900 Commonwealth Avenue, $3^{\text {rd }}$ Fl, Boston, Massachusetts, 02215, (617) 278-0808 phone, (617) 731-3843 fax, jdanik@ partners.org; jmanson@ rics.bwh.harvard.edu. Disclosures: Dr. Manson is the Principal Investigator of the VITamin D and OmegA-3 TriaL (VITAL; CA138962), a National Institutes of Health sponsored trial of vitamin D supplementation in the prevention of cancer and cardiovascular disease.
} 
lower dietary and supplemental vitamin D intakes than whites. ${ }^{20,21}$ Obese individuals are also at above-average risk, presumably because of decreased bioavailability of this fatsoluble vitamin. ${ }^{22-24}$ Given the aging population and rising obesity prevalence, ${ }^{25}$ low vitamin $\mathrm{D}$ status is an increasingly important public health issue.

\section{VITAMIN D AND CARDIOVASCULAR DISEASE}

There are gaps in knowledge in terms of understanding the role of vitamin D in the prevention of cardiovascular disease. Data from laboratory studies, ecologic studies 26,27 , epidemiologic investigations ${ }^{28-31}$ suggest a protective effect for vitamin D against CVD. Mechanisms by which vitamin D may prevent these diseases are shown in Figure 1. ${ }^{32}$

The vitamin D receptor is expressed in cells throughout the vascular system. Many cell types, including vascular smooth muscle cells, endothelial cells, and cardiomyocytes, produce 1a-hydroxylase, which converts 25 -hydroxyvitamin D to calcitriol, the natural ligand of the vitamin D receptor. Calcitriol has been shown to inhibit vascular smooth muscle cell proliferation, regulate the renin-angiotensin system, decrease coagulation, and exhibit anti-inflammatory properties.

\section{Observational and ecological studies}

Ecological studies have suggested higher cardiovascular disease mortality during the winter and in regions with less solar UV-B exposure. Some, but not all, observational studies suggest an inverse association between 25-hydroxyvitamin D levels and clinical cardiovascular disease events. The AHRQ report identified 4 relevant observational studies. The Framingham Offspring Study ${ }^{29}$ and the Health Professionals Follow-up Study ${ }^{28}$ found significant inverse associations between 25-hydroxyvitamin D levels and incident cardiovascular disease events. However, a closer look at the former study indicated that the relationship between 25 -hydroxyvitamin $\mathrm{D}$ and cardiovascular disease was nonlinear and reached a plateau between 20 and $30 \mathrm{ng} / \mathrm{mL}$, with a suggestion of slightly increased risk at higher 25-hydroxyvitamin D levels. In addition, the Third National Health and Nutrition Examination Survey (NHANES III) found no significant association between serum 25hydroxyvitamin D and cardiovascular disease mortality, although persons in the lowest quartile had a $26 \%$ increase in total mortality. ${ }^{34}$ The NHANES III analysis suggested a similar U-shaped relationship for 25-hydroxyvitamin D, with increased total mortality not only at low $(<20 \mathrm{ng} / \mathrm{mL})$ but also at high $(>50 \mathrm{ng} / \mathrm{mL})$ levels. Other observational studies have shown mixed results. ${ }^{35}$ Although the observational evidence is suggestive of increased risks associated with low levels of serum 25-hydroxyvitamin D, confounding by obesity and behavioral factors cannot be excluded. Although measures of serum 25-hydroxyvitamin D are considered useful markers of vitamin D exposure, correlation between these levels and health outcomes in observational studies do not prove causation. Possible confounders exist such as obesity (due to depositioin primarily in adipose tissue), sun exposure, physical activity (correlated with time outdoors) and nutritional status. Other factors such as ethnicity, skin pigmentation and medications may also affect serum 25-hydroxyvitamin D levels.

\section{Randomized trials}

There is a paucity of randomized controlled trials of vitamin D and cardiovascular disease events and absence of any trials with cardiovascular disease as the primary prespecified outcome. ${ }^{2,3}$ A British trial that tested 100000 IU of vitamin $\mathrm{D}_{3}$ or placebo every 4 months (equivalent to $\sim 833 \mathrm{IU} / \mathrm{d}$ ) for up to 5 years, with cardiovascular disease as a secondary outcome, showed null results. In a small 1-year Australian trial, vitamin D (1000 IU/d) added to calcium supplementation vs. calcium alone was associated with a nonsignificantly 
lower risk of ischemic heart disease events and no difference in the risk of stroke. When data from these 2 trials were combined, the pooled relative risk (RR) for cardiovascular disease was 0.90 (95\% confidence interval [CI], 0.77-1.05) for vitamin D. ${ }^{35}$ The recently published Randomised Evaluation of Calcium or Vitamin D (RECORD) trial showed no effects of vitamin D on all cause and vascular-disease mortality but tested only 800 IU of vitamin D daily. ${ }^{36,37}$ postmenopausal women were randomly assigned to a daily combination of calcium (1000 mg) and low-dose vitamin $\mathrm{D}_{3}$ (400 IU) or to placebo and followed for a mean of 7 years-found that the intervention did not reduce risk for cancer, coronary heart disease, or stroke, ${ }^{38,39}$ but its effect on blood levels of 25-hydroxyvitamin D [25(OH)D], the major circulating vitamin D metabolite, was small. In a pooled analysis of 3 trials of combination calcium plus vitamin D vs placebo, including the Women's Health Initiative (WHI), the RR for cardiovascular disease was 1.04 (95\% CI, 0.92-1.18). ${ }^{35}$ Thus, the conclusion of both the IOM Committee ${ }^{2}$ and recent systematic reviews ${ }^{3,35}$ was that the evidence was inconsistent and insufficient to prove a cause and effect relationship between vitamin D and CVD. There have thus far been no completed prospective randomized trials of vitamin $\mathrm{D}$ and incident cardiovascular disease at doses adequate to produce meaningful changes in $25(\mathrm{OH}) \mathrm{D}$ levels or designed to assess CVD as a primary prespecified outcome.

\section{VITAMIN D AND CVD RISK FACTORS}

There is evolving data about the possible relationship of vitamin D with CVD risk factors, some of which are summarized in this section. Figure 2 summarizes hypothesized mechanisms underlying the interrelationships among vitamin D deficiency and several CVD risk factors.

\section{Vitamin D and inflammation}

Vitamin D may attenuate inflammation. VDR signaling inhibits proliferation of T-cells, ${ }^{40,41}$ and transcription of inflammatory cytokines. ${ }^{42,43} 1,25(\mathrm{OH})_{2} \mathrm{D}$ inhibits lymphocyte proliferation and production of antibodies and lymphokines. Vitamin D may induce an inhibitory effect of LPS-driven monokine production. ${ }^{44}$ Combined with VDR-mediated inhibition of dendritic cell maturation, ${ }^{45-48}$ vitamin D in T-cells suppresses Th1-driven inflammatory responses, while promoting a Th2 regulatory phenotype. ${ }^{49}$ In 2 cohorts, $25(\mathrm{OH}) \mathrm{D}$ levels were inversely associated with $\mathrm{CRP}^{50}$ and interleukin 6 (IL6), ${ }^{30,51}$ while another study found suppression of TNF-a concentrations. ${ }^{52}$ Vitamin D treatment reduced disease severity in patients with rheumatoid arthritis, ${ }^{53,54}$ psoriasis, ${ }^{55-57}$ and scleroderma. ${ }^{58}$ Two trials analyzed vitamin D therapy on CRP in special populations ${ }^{59,60}$ with mixed results: the first study showed no effects on C-reactive protein or fibrinogen with vitamin D supplementation in elderly individuals. ${ }^{59}$ The latter showed a 50\% reduction in CRP in participants with kidney disease when given a vitamin D analogue. ${ }^{60}$ Clarification of conflicting data regarding vitamin $\mathrm{D}$ and inflammation is needed.

\section{Vitamin $D$ and blood pressure}

Vitamin D may affect the renin-angiotensin system, ${ }^{61}$ exert beneficial effects on vascular smooth muscle cells, ${ }^{5,62}$ the endothelium, ${ }^{63,64-67}$ and cardiomyocytes. ${ }^{68}$ VDR knockout mice have elevated circulating levels of renin and angiotensin II and develop hypertension. ${ }^{61}$ A similar phenotype occurs in mice lacking the 1a-hydroxylase gene. 69 Injection of mice with $1,25(\mathrm{OH})_{2} \mathrm{D}$ analogs suppresses renin production in vivo, ${ }^{70}$ and negatively regulates the expression of the angiotensinogen gene. ${ }^{71,72}$ Small human studies have reported cross-sectional associations between vitamin $\mathrm{D}$ and renin activity. ${ }^{73,74} \mathrm{~A}$ recent trial of vitamin D supplementation showed a $14 \mathrm{mmHg}$ decrease in SBP. in patients with type 2 diabetes. ${ }^{75}$ However, blood pressures findings in other randomized trials have been inconsistent. ${ }^{2,76}$ 


\section{Vitamin D and insulin resistance}

Vitamin D deficiency is associated with impaired glucose tolerance and reduced insulin turnover and insulin sensitivity. ${ }^{77-80}$ Furthermore, vitamin D repletion improves glucose clearance in vitamin D-deficient animals independent of other nutritional factors. ${ }^{77}$ Human studies also support the association between vitamin $\mathrm{D}$ and insulin sensitivity. Chiu et al. reported a positive correlation between $25(\mathrm{OH}) \mathrm{D}$ and insulin sensitivity indices in healthy volunteers, after multivariate analyses that included potential covariates of age, sex, ethnicity, body mass index, waist-hip ratio, systolic and diastolic blood pressure and season. ${ }^{81}$ Among 5,677 adults in New Zealand, 25(OH)D levels were lower among individuals diagnosed with impaired glucose tolerance compared to controls, after matching for age, sex and ethnicity. ${ }^{82}$ In the Framingham Offspring Study, plasma 25(OH)D levels in the lowest compared to highest tertile were associated with a $1.6 \%$ higher fasting plasma glucose, a $9.8 \%$ higher fasting insulin, and a $12.7 \%$ higher HOMA-IR index (homeostasis model assessment of insulin resistance). ${ }^{83}$ In a prospective study among 524 adults, baseline 25(OH)D levels were inversely associated with fasting insulin and HOMA-IR 10 years later. $^{84}$

\section{VITAMIN D AND TYPE 2 DIABETES}

The role of calcitriol in the synthesis and secretion of insulin and regulation of calcium trafficking in beta islet cells, and its effects on insulin action have been established in both rodent models and cell culture. ${ }^{2}$ Although some observational studies have shown an inverse relationship between higher vitamin D intake or serum 25-hydroxyvitamin D and risk of type 2 diabetes, a systematic review and meta-analysis ${ }^{85}$ with a large body of observational evidence and 6 intervention studies with vitamin D supplementation found generally neutral results. Studies published after the IOM report ${ }^{2}$ have shown mixed results; there was either a higher risk of prediabetes in individuals (NHANES III) with 25hydroxyvitamin D levels below $18 \mathrm{ng} / \mathrm{mL}^{86}$ or no association between serum 25 hydroxyvitamin D and risk of type 2 diabetes in a Canadian population or in the WHI. Randomized trials of vitamin D supplementation and risk of type 2 diabetes have had inconsistent results. In the Randomised Evaluation of Calcium or vitamin D (RECORD) trial, there was no effect of $800 \mathrm{IU} / \mathrm{d}$ of vitamin $\mathrm{D}_{3}$ supplementation (with or without 1000 $\mathrm{mg}$ of calcium carbonate) on incident diabetes over 2 to 5 years (fracture was the primary outcome variable and diabetes outcomes were self-reported). ${ }^{86}$

In separate studies of vitamin D supplementation with 4000 IU/d or 120000 IU every 2 weeks in South Asian overweight women and obese men, respectively, insulin sensitivity significantly improved compared with placebo. ${ }^{87}$ However, another study in overweight adults in Germany found no relationship between vitamin D supplementation (3300 IU/d) with glucose metabolism during weight loss. ${ }^{88}$ In a post hoc analysis of a trial testing the effects of 3 years of supplementation with $700 \mathrm{IU}$ of vitamin D and $500 \mathrm{mg}$ of calcium daily on bone health, individuals with impaired fasting glucose were found to have a lower increase in fasting glucose levels and less insulin resistance compared with placebo controls ${ }^{89}$ In patients with established type 2 diabetes, vitamin D has not been shown to improve insulin resistance or glucose metabolism. ${ }^{2}$ Thus, the overall evidence from clinical trials and observational research ${ }^{2,3,85,86,90}$ is insufficient to establish a causal relationship between vitamin D supplementation and type 2 diabetes prevention.

\section{VITAMIN D AND STATIN-INDUCED MYALGIAS}

There is also evidence for the relationship of vitamin D deficiency to statin myopathy. ${ }^{91-93}$ One study ${ }^{93}$ reported resolution of myalgia after restoring vitamin D levels in vitamin Ddeficient individuals. The authors speculated that patients with concurrent vitamin D 
deficiency may reflect a reversible interaction between vitamin D deficiency and statins on skeletal muscle. It has been hypothesized that a potential mechanism may be via the induction of CYP enzymes by vitamin D, as vitamin D is known to activate CYP3A4 94,95 which may help in the metabolism of certain statins, ${ }^{96}$ In addition, hydroxylated vitamin D derivatives may also possess 3-hydroxy-3-methyl-glutaryl-Coenzme A (HMG-CoA) reductase activity. ${ }^{97}$ However, data from the Treating to New Targets (TNT) trial have suggested no relationship between vitamin D levels and statin-induced myalgias. ${ }^{98}$ These data remain hypothesis-generating and no large scale randomized data exist yet in this regard.

\section{SUMMARY}

There is biological plausibility for a role of vitamin D in the prevention of cardiovascular disease and diabetes, but less so than would be anticipated relative to the current popularity of the supplement in the U.S. There is currently insufficient data to inform nutritional requirements. No large-scale randomized trials have been completed with cardiovascular disease or diabetes as the primary prespecified outcomes. Although the observational evidence is suggestive of increased risks associated with low levels of serum 25hydroxyvitamin D, confounding by obesity and behavioral factors cannot be excluded. More research is needed to elucidate whether higher intakes of vitamin D (between the recommended dietary allowance and the tolerable upper intake level) or serum 25hydroxyvitamin $\mathrm{D}$ levels in the range of 20 to $50 \mathrm{ng} / \mathrm{mL}$ influence cardiovascular disease or diabetes risk. New randomized trials assessing the role of supplementation with vitamin D in cardiovascular disease and type 2 diabetes prevention are in progress, such as the Vitamin D and Omega-3 trial (VITAL, NCT01169259), the Vitamin D, Insulin Resistance and Cardiovascular Disease trial (NCT00736632) and the Vitamin D Supplementation and Metabolism in Vitamin D Deficient Elderly trial (NCT01145703). Because of the involvement of the authors of this chapter in the first trial, the next section briefly describes the design of the ongoing VITAL trial. ${ }^{33}$

\section{ONGOING RESEARCH}

\section{The Vitamin D and Omega-3 (VITAL) Trial}

VITAL is one of the ongoing trials seeking to address the role of vitamin $\mathrm{D}$ and marine omega-3 fatty acids in the primary prevention of cancer and CVD. It is a randomized, double-blind, placebo-controlled clinical trial among 20,000 U.S. men and women without cancer or CVD at baseline, who are selected on age only (men aged $\geq 50$ and women aged 255), with an oversampling of blacks. Blacks are at higher risk of vitamin D deficiency and are also at higher risk for certain cancers (e.g., prostate cancer) ${ }^{99}$ and cardiovascular events (e.g., stroke) ${ }^{21}$, as well as mortality from CVD ${ }^{21}$, so it is critical to test the effect of vitamin $\mathrm{D}$ supplementation in this group. In a $2 \times 2$ factorial design, participants will be randomized to vitamin $\mathrm{D}_{3}$ (cholecalciferol; $2000 \mathrm{IU} /$ day) with or without marine omega-3 fatty acids (Omacor® fish oil, EPA + DHA, $1 \mathrm{~g} / \mathrm{d}$ ) supplements (or placebos) independently. The mean treatment period will be 5 years.

\section{Intervention}

With regard to the vitamin $\mathrm{D}_{3}$ dose of $2000 \mathrm{IU} /$ day, careful review of the literature suggested that this dose provides the best balance of efficacy and safety. We sought to obtain a large-enough difference in vitamin $\mathrm{D}$ status between the treatment and placebo groups to detect benefits for the primary endpoints of cancer and CVD. VITAL was designed in 2008, when the recommended dietary intakes set by the Institute of Medicine (IOM), were $400 \mathrm{IU} /$ day for adults aged 50-70 and $600 \mathrm{IU} /$ day for adults aged $>70 .{ }^{100} \mathrm{In}$ 2011 , the IOM released RDAs for these age groups of 600 IU/day and 800 IU/day, 
respectively. ${ }^{2}$ These RDAs correspond to a serum $25(\mathrm{OH}) \mathrm{D}$ level of $50 \mathrm{nmol} / \mathrm{L}$ and are sufficient for the maintenance of bone health in at least $97.5 \%$ of the North American population. Nevertheless, accumulating data suggest that vitamin D intakes above these RDAs may be necessary for maximal health benefits. In a review of studies of serum $25(\mathrm{OH}) \mathrm{D}$ in relation to various outcomes, including colorectal cancer, falls, fractures, physical functioning, and dental health, Bischoff-Ferrari et al. ${ }^{101}$ found that advantageous $25(\mathrm{OH}) \mathrm{D}$ levels began at $75 \mathrm{nmol} / \mathrm{L}$, and optimal levels were between $90-100 \mathrm{nmol} / \mathrm{L}$. The average older individual requires an oral vitamin $\mathrm{D}_{3}$ intake of at least $800-1000 \mathrm{IU} /$ day to achieve a serum $25(\mathrm{OH}) \mathrm{D}$ of $75 \mathrm{nmol} / \mathrm{L}$. ${ }^{102}$ Among postmenopausal women in the Women's Health Initiative, 400 IU/day of vitamin $\mathrm{D}_{3}$ was estimated to have raised median plasma $25(\mathrm{OH}) \mathrm{D}$ from 42.3 to only $54.1 \mathrm{nmol} / \mathrm{L}$. ${ }^{38,103} \mathrm{In}$ addition, a study by Aloia et al. ${ }^{104}$ showed a nonlinear dose-response relation between serum $25(\mathrm{OH}) \mathrm{D}$ and vitamin $\mathrm{D}$ intake, with the rate of increase in serum levels slowing at higher levels of intake. Extrapolation of the Women's Health Initiative data, along with consideration of the Aloia et al. findings, suggest that $2000 \mathrm{IU}$ of vitamin $\mathrm{D}_{3}$ would be required to reach the postulated optimal value of $90 \mathrm{nmol} / \mathrm{L}$ in the active vitamin $\mathrm{D}$ group in VITAL. The difference in achieved 25(OH)D levels between the active treatment and placebo groups is expected to be approximately $50 \mathrm{nmol} / \mathrm{L}$. A secondary arm will test omega-3 fatty acids on the same outcomes.

\section{Study design}

Baseline blood samples will be collected in at least $80 \%$ of participants $(n=16,000)$, with follow-up blood collection in about 6000 participants. A summary of the study design is provided in Figure 3 adapted from Manson et al. ${ }^{33}$

Follow-up questionnaires every 6 months will assess treatment compliance (plasma biomarker measures will also assess compliance in a random sample of participants), use of non-study drugs or supplements, occurrence of endpoints, and cancer and vascular risk factors. Endpoints will be confirmed by medical record review by a committee of physicians blinded to treatment assignment and deaths will be ascertained through the National Death Index-Plus and other sources. Ancillary studies, including clinic visits for in-depth phenotyping of 1000 participants, will make use of the randomized design to investigate whether these agents affect risk for diabetes and glucose intolerance; hypertension; cognitive decline; depression; osteoporosis and fracture; physical disability and falls; asthma and other respiratory diseases; infections; rheumatoid arthritis, systemic lupus erythematosus, thyroid diseases, and other autoimmune disorders, among others.

\section{CONCLUSION}

Despite biological plausibility for a role of vitamin D in the prevention of cardiovascular disease and diabetes, randomized trial data need to be completed before there is sufficient data to inform nutritional requirements. Other emerging hypotheses such as the potential relationship between circulating vitamin $\mathrm{D}$ levels and statin-induced myalgias require further corroboration.

\section{References and Recommended Reading}

1•. Ross AC, Manson JE, Abrams SA, et al. The 2011 report on dietary reference intakes for calcium and vitamin $\mathrm{d}$ from the institute of medicine: what clinicians need to know. J Clin Endocrinol Metab. Jan; 2011 96(1):53-58. This paper provides the clinician with a review of the current dietary guidelines. [PubMed: 21118827]

2. Institute of Medicine. Dietary reference intakes for calcium and vitamin D. Washington, D.C: National Academies Press; 2011. 
3•. Chung, M.; Balk, EM.; Brendel, M., et al. Vitamin D and calcium: a systematic review of health outcomes. Evidence report/technology assessment no.183. Agency for Healthcare Research and Quality; Rockville, MD: Aug. 2009 This paper is the AHRQ's systemic review of the literature

4. Norman AW. From vitamin D to hormone D: fundamentals of the vitamin D endocrine system essential for good health. Am J Clin Nutr. Aug; 2008 88(2):491S-499S. [PubMed: 18689389]

5. Holick MF. Vitamin D deficiency. N Engl J Med. Jul 19; 2007 357(3):266-281. [PubMed: 17634462]

6. Chun RF, Adams JS, Hewison M. Back to the future: a new look at 'old' vitamin D. J Endocrinol. Aug; 2008 198(2):261-269. [PubMed: 18495944]

7. Hewison M, Burke F, Evans KN, et al. Extra-renal 25-hydroxyvitamin D3-1[alpha]-hydroxylase in human health and disease. The Journal of Steroid Biochemistry and Molecular Biology. 2007; 103(3-5):316-321. [PubMed: 17368179]

8. Adams JS, Hewison M. Unexpected actions of vitamin D: new perspectives on the regulation of innate and adaptive immunity. Nat Clin Pract Endocrinol Metab. Feb; 2008 4(2):80-90. [PubMed: 18212810]

9. Zhou S, LeBoff MS, Glowacki J. Vitamin D metabolism and action in human bone marrow stromal cells. Endocrinology. Jan; 2010 151(1):14-22. [PubMed: 19966181]

10. Holick MF, Siris ES, Binkley N, et al. Prevalence of Vitamin D inadequacy among postmenopausal North American women receiving osteoporosis therapy. J Clin Endocrinol Metab. Jun; 2005 90(6):3215-3224. [PubMed: 15797954]

11. Looker AC, Dawson-Hughes B, Calvo MS, Gunter EW, Sahyoun NR. Serum 25-hydroxyvitamin D status of adolescents and adults in two seasonal subpopulations from NHANES III. Bone. May; 2002 30(5):771-777. [PubMed: 11996918]

12. Rosen CJ. Clinical practice. Vitamin D insufficiency. N Engl J Med. Jan 20; 2011 364(3):248-254. [PubMed: 21247315]

13. Looker AC, Pfeiffer CM, Lacher DA, Schleicher RL, Picciano MF, Yetley EA. Serum 25hydroxyvitamin D status of the US population: 1988-1994 compared with 2000-2004. Am J Clin Nutr. Dec; 2008 88(6):1519-1527. [PubMed: 19064511]

14. Cauley JA, Lacroix AZ, Wu L, et al. Serum 25-hydroxyvitamin D concentrations and risk for hip fractures. Ann Intern Med. Aug 19; 2008 149(4):242-250. [PubMed: 18711154]

15. Chapuy MC, Arlot ME, Duboeuf F, et al. Vitamin D3 and calcium to prevent hip fractures in the elderly women. N Engl J Med. Dec 3; 1992 327(23):1637-1642. [PubMed: 1331788]

16. Chapuy MC, Pamphile R, Paris E, et al. Combined calcium and vitamin D3 supplementation in elderly women: confirmation of reversal of secondary hyperparathyroidism and hip fracture risk: the Decalyos II study. Osteoporos Int. Mar; 2002 13(3):257-264. [PubMed: 11991447]

17. LeBoff MS, Hawkes WG, Glowacki J, Yu-Yahiro J, Hurwitz S, Magaziner J. Vitamin Ddeficiency and post-fracture changes in lower extremity function and falls in women with hip fractures. Osteoporos Int. Sep; 2008 19(9):1283-1290. [PubMed: 18373057]

18. LeBoff MS, Kohlmeier L, Hurwitz S, Franklin J, Wright J, Glowacki J. Occult vitamin D deficiency in postmenopausal US women with acute hip fracture. Jama. Apr 28; 1999 281(16): 1505-1511. [PubMed: 10227320]

19. Pieper CF, Colon-Emeric C, Caminis J, et al. Distribution and correlates of serum 25hydroxyvitamin D levels in a sample of patients with hip fracture. Am J Geriatr Pharmacother. Dec; 2007 5(4):335-340. [PubMed: 18179991]

20. Moore CE, Murphy MM, Holick MF. Vitamin D intakes by children and adults in the United States differ among ethnic groups. J Nutr. Oct; 2005 135(10):2478-2485. [PubMed: 16177216]

21. Harris SS. Vitamin D and African Americans. J Nutr. Apr; 2006 136(4):1126-1129. [PubMed: 16549493]

22. Zadshir A, Tareen N, Pan D, Norris K, Martins D. The prevalence of hypovitaminosis D among US adults: data from the NHANES III. Ethn Dis. Autumn;2005 15(4 Suppl 5):S5-97-101.

23. Harris SS, Dawson-Hughes B. Reduced sun exposure does not explain the inverse association of 25-hydroxyvitamin D with percent body fat in older adults. J Clin Endocrinol Metab. Aug; 2007 92(8):3155-3157. [PubMed: 17535990] 
24. Martins D, Wolf M, Pan D, et al. Prevalence of cardiovascular risk factors and the serum levels of 25-hydroxyvitamin D in the United States: data from the Third National Health and Nutrition Examination Survey. Arch Intern Med. Jun 11; 2007 167(11):1159-1165. [PubMed: 17563024]

25. Flegal KM, Carroll MD, Ogden CL, Curtin LR. Prevalence and trends in obesity among US adults, 1999-2008. Jama. Jan 20; 2010 303(3):235-241. [PubMed: 20071471]

26. Zittermann A. Vitamin D and disease prevention with special reference to cardiovascular disease. Prog Biophys Mol Biol. Sep; 2006 92(1):39-48. [PubMed: 16600341]

27. Zittermann A, Koerfer R. Vitamin D in the prevention and treatment of coronary heart disease. Curr Opin Clin Nutr Metab Care. Nov; 2008 11(6):752-757. [PubMed: 18827580]

28. Giovannucci E, Liu Y, Hollis BW, Rimm EB. 25-hydroxyvitamin D and risk of myocardial infarction in men: a prospective study. Arch Intern Med. Jun 9; 2008 168(11):1174-1180. [PubMed: 18541825]

29. Wang TJ, Pencina MJ, Booth SL, et al. Vitamin D deficiency and risk of cardiovascular disease. Circulation. Jan 29; 2008 117(4):503-511. [PubMed: 18180395]

30. Dobnig H, Pilz S, Scharnagl H, et al. Independent association of low serum 25-hydroxyvitamin d and 1,25-dihydroxyvitamin d levels with all-cause and cardiovascular mortality. Arch Intern Med. Jun 23; 2008 168(12):1340-1349. [PubMed: 18574092]

31. Anderson JL, May HT, Horne BD, et al. Relation of vitamin D deficiency to cardiovascular risk factors, disease status, and incident events in a general healthcare population. Am J Cardiol. Oct 1; 2010 106(7):963-968. [PubMed: 20854958]

32. Bassuk SS, Manson JE. Does vitamin D protect against cardiovascular disease? Journal of cardiovascular translational research. Sep; 2009 2(3):245-250. [PubMed: 20560014]

33•. Manson JE, Bassuk SS, Lee IM, et al. The VITamin D and OmegA-3 TriaL (VITAL): rationale and design of a large randomized controlled trial of vitamin D and marine omega-3 fatty acid supplements for the primary prevention of cancer and cardiovascular disease. Contemporary clinical trials. Jan; 2012 33(1):159-171. This paper provides a detailed rationale of the VITAL trial. [PubMed: 21986389]

34. Melamed ML, Michos ED, Post W, Astor B. 25-hydroxyvitamin D levels and the risk of mortality in the general population. Arch Intern Med. Aug 11; 2008 168(15):1629-1637. [PubMed: 18695076]

35. Wang L, Manson JE, Song Y, Sesso HD. Systematic review: Vitamin D and calcium supplementation in prevention of cardiovascular events. Ann Intern Med. Mar 2; 2010 152(5): 315-323. [PubMed: 20194238]

36. Avenell A, Maclennan GS, Jenkinson DJ, et al. Long-Term Follow-Up for Mortality and Cancer in a Randomized Placebo-Controlled Trial of Vitamin D3 and/or Calcium (RECORD Trial). J Clin Endocrinol Metab. Nov 23.2011

37. Liu S, Song Y, Ford ES, Manson JE, Buring JE, Ridker PM. Dietary calcium, vitamin D, and the prevalence of metabolic syndrome in middle-aged and older U.S. women. Diabetes Care. Dec; 2005 28(12):2926-2932. [PubMed: 16306556]

38. Wactawski-Wende J, Kotchen JM, Anderson GL, et al. Calcium plus vitamin D supplementation and the risk of colorectal cancer. N Engl J Med. Feb 16; 2006 354(7):684-696. [PubMed: 16481636]

39. Jackson RD, LaCroix AZ, Gass M, et al. Calcium plus vitamin D supplementation and the risk of fractures. N Engl J Med. Feb 16; 2006 354(7):669-683. [PubMed: 16481635]

40. van Etten E, Mathieu C. Immunoregulation by 1,25-dihydroxyvitamin D3: basic concepts. J Steroid Biochem Mol Biol. Oct; 2005 97(1-2):93-101. [PubMed: 16046118]

41. Miyakoshi H, Aoki T, Hirasawa Y. Immunological effects of 1alpha-hydroxycholecalciferol (1alpha-OH-D3) and its metabolites. Clin Nephrol. Sep; 1981 16(3):119-125. [PubMed: 6895354]

42. D’Ambrosio D, Cippitelli M, Cocciolo MG, et al. Inhibition of IL-12 production by 1,25dihydroxyvitamin D3. Involvement of NF-kappaB downregulation in transcriptional repression of the p40 gene. J Clin Invest. Jan 1; 1998 101(1):252-262. [PubMed: 9421488]

43. Alroy I, Towers TL, Freedman LP. Transcriptional repression of the interleukin-2 gene by vitamin D3: direct inhibition of NFATp/AP-1 complex formation by a nuclear hormone receptor. Mol Cell Biol. Oct; 1995 15(10):5789-5799. [PubMed: 7565732] 
44. Muller K, Haahr PM, Diamant M, Rieneck K, Kharazmi A, Bendtzen K. 1,25-Dihydroxyvitamin D3 inhibits cytokine production by human blood monocytes at the post-transcriptional level. Cytokine. Nov; 1992 4(6):506-512. [PubMed: 1337987]

45. van Halteren AG, van Etten E, de Jong EC, Bouillon R, Roep BO, Mathieu C. Redirection of human autoreactive T-cells Upon interaction with dendritic cells modulated by TX527, an analog of 1,25 dihydroxyvitamin D(3). Diabetes. Jul; 2002 51(7):2119-2125. [PubMed: 12086941]

46. Penna G, Adorini L. 1 Alpha,25-dihydroxyvitamin D3 inhibits differentiation, maturation, activation, and survival of dendritic cells leading to impaired alloreactive T cell activation. $\mathrm{J}$ Immunol. Mar 1; 2000 164(5):2405-2411. [PubMed: 10679076]

47. Griffin MD, Lutz WH, Phan VA, Bachman LA, McKean DJ, Kumar R. Potent inhibition of dendritic cell differentiation and maturation by vitamin D analogs. Biochem Biophys Res Commun. Apr 21; 2000 270(3):701-708. [PubMed: 10772887]

48. Griffin MD, Lutz W, Phan VA, Bachman LA, McKean DJ, Kumar R. Dendritic cell modulation by 1alpha,25 dihydroxyvitamin D3 and its analogs: a vitamin D receptor-dependent pathway that promotes a persistent state of immaturity in vitro and in vivo. Proc Natl Acad Sci U S A. Jun 5; 2001 98(12):6800-6805. [PubMed: 11371626]

49. White JH. Vitamin D signaling, infectious diseases, and regulation of innate immunity. Infect Immun. Sep; 2008 76(9):3837-3843. [PubMed: 18505808]

50. Kendrick J, Targher G, Smits G, Chonchol M. 25-Hydroxyvitamin D deficiency and inflammation and their association with hemoglobin levels in chronic kidney disease. Am J Nephrol. 2009; 30(1):64-72. [PubMed: 19218791]

51. Shea MK, Booth SL, Massaro JM, et al. Vitamin K and vitamin D status: associations with inflammatory markers in the Framingham Offspring Study. Am J Epidemiol. Feb 1; 2008 167(3): 313-320. [PubMed: 18006902]

52. Schleithoff SS, Zittermann A, Tenderich G, Berthold HK, Stehle P, Koerfer R. Vitamin D supplementation improves cytokine profiles in patients with congestive heart failure: a doubleblind, randomized, placebo-controlled trial. Am J Clin Nutr. Apr; 2006 83(4):754-759. [PubMed: 16600924]

53. Yamauchi Y, Tsunematsu T, Konda S, Hoshino T, Itokawa Y, Hoshizaki H. [A double blind trial of alfacalcidol on patients with rheumatoid arthritis (RA)]. Ryumachi. Feb; 1989 29(1):11-24. [PubMed: 2662431]

54. Andjelkovic Z, Vojinovic J, Pejnovic N, et al. Disease modifying and immunomodulatory effects of high dose 1 alpha $(\mathrm{OH})$ D3 in rheumatoid arthritis patients. Clin Exp Rheumatol. Jul-Aug;1999 17(4):453-456. [PubMed: 10464556]

55. Perez A, Raab R, Chen TC, Turner A, Holick MF. Safety and efficacy of oral calcitriol $(1,25-$ dihydroxyvitamin D3) for the treatment of psoriasis. Br J Dermatol. Jun; 1996 134(6):1070-1078. [PubMed: 8763427]

56. Morimoto S, Yoshikawa K, Kozuka T, et al. Treatment of psoriasis vulgaris with oral 1 alpha,25dihydroxyvitamin D3--report of two cases. J Dermatol. Feb; 1987 14(1):59-62. [PubMed: 3301950]

57. El-Azhary RA, Peters MS, Pittelkow MR, Kao PC, Muller SA. Efficacy of vitamin D3 derivatives in the treatment of psoriasis vulgaris: a preliminary report. Mayo Clin Proc. Sep; 1993 68(9):835841. [PubMed: 8396699]

58. Elst EF, Van Suijlekom-Smit LW, Oranje AP. Treatment of linear scleroderma with oral 1,25dihydroxyvitamin D3 (calcitriol) in seven children. Pediatr Dermatol. Jan-Feb;1999 16(1):53-58. [PubMed: 10028002]

59. Bjorkman MP, Sorva AJ, Tilvis RS. C-reactive protein and fibrinogen of bedridden older patients in a six-month vitamin D supplementation trial. J Nutr Health Aging. May; 2009 13(5):435-439. [PubMed: 19390750]

60. Alborzi P, Patel NA, Peterson C, et al. Paricalcitol reduces albuminuria and inflammation in chronic kidney disease: a randomized double-blind pilot trial. Hypertension. Aug; 2008 52(2): 249-255. [PubMed: 18606901] 
61. Li YC, Kong J, Wei M, Chen ZF, Liu SQ, Cao LP. 1,25-Dihydroxyvitamin D(3) is a negative endocrine regulator of the renin-angiotensin system. J Clin Invest. Jul; 2002 110(2):229-238. [PubMed: 12122115]

62. Bouillon R, Carmeliet G, Verlinden L, et al. Vitamin D and human health: lessons from vitamin D receptor null mice. Endocr Rev. Oct; 2008 29(6):726-776. [PubMed: 18694980]

63. Tarcin O, Yavuz DG, Ozben B, et al. Effect of vitamin D deficiency and replacement on endothelial function in asymptomatic subjects. J Clin Endocrinol Metab. Oct; 2009 94(10):40234030. [PubMed: 19584181]

64. Kahonen M, Nappi S, Jolma P, et al. Vascular influences of calcium supplementation and vitamin D-induced hypercalcemia in NaCl-hypertensive rats. J Cardiovasc Pharmacol. Sep; 2003 42(3): 319-328. [PubMed: 12960676]

65. Wakasugi M, Noguchi T, Inoue M, et al. Vitamin D3 stimulates the production of prostacyclin by vascular smooth muscle cells. Prostaglandins. Aug; 1991 42(2):127-136. [PubMed: 1775635]

66. Wong MS, Delansorne R, Man RY, Vanhoutte PM. Vitamin D derivatives acutely reduce endothelium-dependent contractions in the aorta of the spontaneously hypertensive rat. Am J Physiol Heart Circ Physiol. Jul; 2008 295(1):H289-296. [PubMed: 18487433]

67. Zittermann A, Koerfer R. Protective and toxic effects of vitamin D on vascular calcification: clinical implications. Mol Aspects Med. Dec; 2008 29(6):423-432. [PubMed: 18538838]

68. Zittermann A, Schleithoff SS, Gotting C, et al. Poor outcome in end-stage heart failure patients with low circulating calcitriol levels. Eur J Heart Fail. Mar; 2008 10(3):321-327. [PubMed: 18304873]

69. Zhou C, Lu F, Cao K, Xu D, Goltzman D, Miao D. Calcium-independent and 1,25(OH)2D3dependent regulation of the renin-angiotensin system in 1alpha-hydroxylase knockout mice. Kidney Int. Jul; 2008 74(2):170-179. [PubMed: 18385669]

70. Qiao G, Kong J, Uskokovic M, Li YC. Analogs of 1alpha,25-dihydroxyvitamin D(3) as novel inhibitors of renin biosynthesis. J Steroid Biochem Mol Biol. Jun; 2005 96(1):59-66. [PubMed: 15878826]

71. Deb DK, Chen Y, Zhang Z, et al. 1,25-Dihydroxyvitamin D3 suppresses high glucose-induced angiotensinogen expression in kidney cells by blocking the NF-\{kappa\}B pathway. Am J Physiol Renal Physiol. May; 2009 296(5):F1212-1218. [PubMed: 19193728]

72. Freundlich M, Quiroz Y, Zhang Z, et al. Suppression of renin-angiotensin gene expression in the kidney by paricalcitol. Kidney Int. Dec; 2008 74(11):1394-1402. [PubMed: 18813285]

73. Resnick LM, Muller FB, Laragh JH. Calcium-regulating hormones in essential hypertension. Relation to plasma renin activity and sodium metabolism. Ann Intern Med. Nov; 1986 105(5): 649-654. [PubMed: 3532893]

74. Burgess ED, Hawkins RG, Watanabe M. Interaction of 1,25-dihydroxyvitamin D and plasma renin activity in high renin essential hypertension. Am J Hypertens. Dec; 1990 3(12 Pt 1):903-905. [PubMed: 2081010]

75. Sugden JA, Davies JI, Witham MD, Morris AD, Struthers AD. Vitamin D improves endothelial function in patients with Type 2 diabetes mellitus and low vitamin D levels. Diabet Med. Mar; 2008 25(3):320-325. [PubMed: 18279409]

76. Shapses SA, Manson JE. Vitamin D and prevention of cardiovascular disease and diabetes: why the evidence falls short. Jama. Jun 22; 2011 305(24):2565-2566. [PubMed: 21693745]

77. Cade C, Norman AW. Vitamin D3 improves impaired glucose tolerance and insulin secretion in the vitamin D-deficient rat in vivo. Endocrinology. Jul; 1986 119(1):84-90. [PubMed: 3013599]

78. Chertow BS, Sivitz WI, Baranetsky NG, Clark SA, Waite A, Deluca HF. Cellular mechanisms of insulin release: the effects of vitamin D deficiency and repletion on rat insulin secretion. Endocrinology. Oct; 1983 113(4):1511-1518. [PubMed: 6352248]

79. Ismail A, Namala R. Impaired glucose tolerance in vitamin D deficiency can be corrected by calcium. J Nutr Biochem. Mar; 2000 11(3):170-175. [PubMed: 10742663]

80. Nyomba BL, Bouillon R, De Moor P. Influence of vitamin D status on insulin secretion and glucose tolerance in the rabbit. Endocrinology. Jul; 1984 115(1):191-197. [PubMed: 6376069]

81. Chiu KC, Chu A, Go VL, Saad MF. Hypovitaminosis D is associated with insulin resistance and beta cell dysfunction. Am J Clin Nutr. May; 2004 79(5):820-825. [PubMed: 15113720] 
82. Scragg R, Holdaway I, Singh V, Metcalf P, Baker J, Dryson E. Serum 25-hydroxyvitamin D3 levels decreased in impaired glucose tolerance and diabetes mellitus. Diabetes Res Clin Pract. Mar; 1995 27(3):181-188. [PubMed: 7555599]

83. Liu E, Meigs JB, Pittas AG, et al. Plasma 25-hydroxyvitamin d is associated with markers of the insulin resistant phenotype in nondiabetic adults. J Nutr. Feb; 2009 139(2):329-334. [PubMed: 19106328]

84. Forouhi NG, Luan J, Cooper A, Boucher BJ, Wareham NJ. Baseline serum 25-hydroxy vitamin d is predictive of future glycemic status and insulin resistance: the Medical Research Council Ely Prospective Study 1990-2000. Diabetes. Oct; 2008 57(10):2619-2625. [PubMed: 18591391]

85. Pittas AG, Lau J, Hu FB, Dawson-Hughes B. The role of vitamin D and calcium in type 2 diabetes. A systematic review and meta-analysis. J Clin Endocrinol Metab. Jun; 2007 92(6):2017-2029. [PubMed: 17389701]

86. Avenell A, Cook JA, MacLennan GS, McPherson GC. Vitamin D supplementation and type 2 diabetes: a substudy of a randomised placebo-controlled trial in older people (RECORD trial, ISRCTN 51647438). Age and ageing. Sep; 2009 38(5):606-609. [PubMed: 19617604]

87. von Hurst PR, Stonehouse W, Coad J. Vitamin D supplementation reduces insulin resistance in South Asian women living in New Zealand who are insulin resistant and vitamin D deficient - a randomised, placebo-controlled trial. Br J Nutr. Feb; 2010 103(4):549-555. [PubMed: 19781131]

88. Zittermann A, Frisch S, Berthold HK, et al. Vitamin D supplementation enhances the beneficial effects of weight loss on cardiovascular disease risk markers. Am J Clin Nutr. May; 2009 89(5): 1321-1327. [PubMed: 19321573]

89. Pittas AG, Harris SS, Stark PC, Dawson-Hughes B. The effects of calcium and vitamin D supplementation on blood glucose and markers of inflammation in nondiabetic adults. Diabetes Care. Apr; 2007 30(4):980-986. [PubMed: 17277040]

90. Shankar A, Sabanayagam C, Kalidindi S. Serum 25-hydroxyvitamin d levels and prediabetes among subjects free of diabetes. Diabetes Care. May; 2011 34(5):1114-1119. [PubMed: 21430085]

91. Ahmed W, Khan N, Glueck CJ, et al. Low serum $25(\mathrm{OH})$ vitamin D levels $(<32 \mathrm{ng} / \mathrm{mL})$ are associated with reversible myositis-myalgia in statin-treated patients. Translational research : the journal of laboratory and clinical medicine. Jan; 2009 153(1):11-16. [PubMed: 19100953]

92. Bell DS. Resolution of statin-induced myalgias by correcting vitamin D deficiency. Southern medical journal. Jul; 2010 103(7):690-692. [PubMed: 20531048]

93. Lee P, Greenfield JR, Campbell LV. Vitamin D insufficiency--a novel mechanism of statininduced myalgia? Clin Endocrinol (Oxf). Jul; 2009 71(1):154-155. [PubMed: 19178510]

94. Drocourt L, Ourlin JC, Pascussi JM, Maurel P, Vilarem MJ. Expression of CYP3A4, CYP2B6, and CYP2C9 is regulated by the vitamin D receptor pathway in primary human hepatocytes. The Journal of biological chemistry. Jul 12; 2002 277(28):25125-25132. [PubMed: 11991950]

95. Thummel KE, Brimer C, Yasuda K, et al. Transcriptional control of intestinal cytochrome P-4503A by 1alpha,25-dihydroxy vitamin D3. Molecular pharmacology. Dec; 2001 60(6):1399_ 1406. [PubMed: 11723248]

96. Bhattacharyya S, Bhattacharyya K, Maitra A. Possible mechanisms of interaction between statins and vitamin D. QJM : monthly journal of the Association of Physicians. May; 2012 105(5):487491. [PubMed: 22323613]

97. Defay R, Astruc ME, Roussillon S, Descomps B, Crastes de Paulet A. DNA synthesis and 3hydroxy-3-methylglutaryl CoA reductase activity in PHA stimulated human lymphocytes: a comparative study of the inhibitory effects of some oxysterols with special reference to side chain hydroxylated derivatives. Biochem Biophys Res Commun. May 31; 1982 106(2):362-372. [PubMed: 7103998]

98. Bittner V, Wenger N, Waters D, DeMicco DA, Messig M, LaRosa J. Vitamin D levels are not related to myalgias in statin-treated patients with stable coronary disease. J Am Coll Cardiol. 2010; 55:Abstract. A177.E1659.

99. American Cancer Society. Cancer Facts \& Figures for African AMericans 2009-2010. Atlanta: American Cancer Society; 2009. 
100. Institute of Medicine Food and Nutrition Board. Dietary reference intakes: calcium, phosphorous, magnesium vitamin D and fluoride. Washington, D.C: National Academies Press; 1999.

101. Bischoff-Ferrari HA, Giovannucci E, Willett WC, Dietrich T, Dawson-Hughes B. Estimation of optimal serum concentrations of 25-hydroxyvitamin D for multiple health outcomes. Am J Clin Nutr. Jul; 2006 84(1):18-28. [PubMed: 16825677]

102. Dawson-Hughes B, Heaney RP, Holick MF, Lips P, Meunier PJ, Vieth R. Estimates of optimal vitamin D status. Osteoporos Int. Jul; 2005 16(7):713-716. [PubMed: 15776217]

103. Giovannucci E, Liu Y, Rimm EB, et al. Prospective study of predictors of vitamin D status and cancer incidence and mortality in men. J Natl Cancer Inst. Apr 5; 2006 98(7):451-459. [PubMed: 16595781]

104. Aloia JF, Patel M, Dimaano R, et al. Vitamin D intake to attain a desired serum 25hydroxyvitamin D concentration. Am J Clin Nutr. Jun; 2008 87(6):1952-1958. [PubMed: 18541590] 
Mechanisms by which Vitamin D May Lower CVD Risk

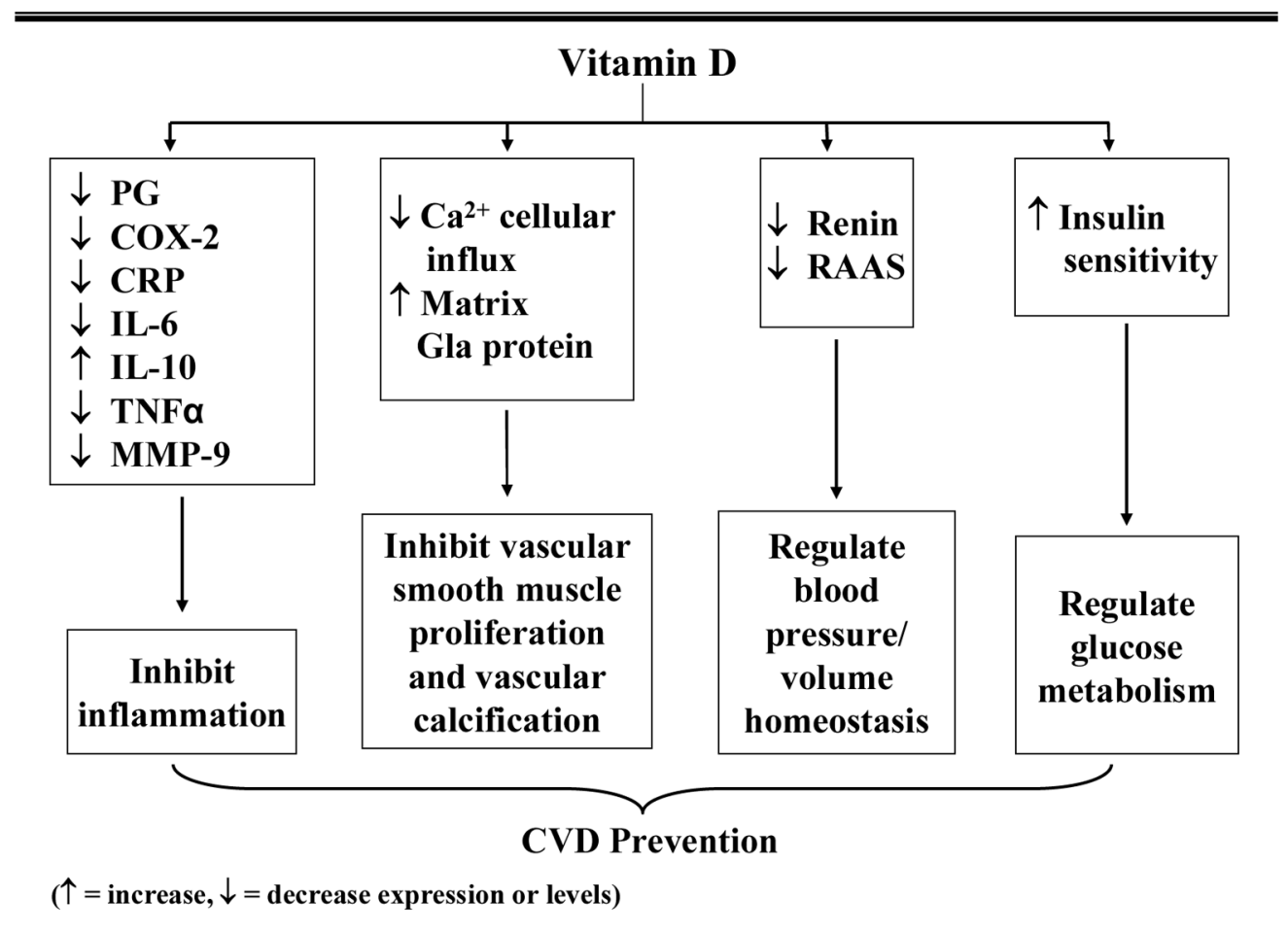

Adapted from: Manson JE, et al. Contemp Clin Trials 2012; 33:159-171.

Figure 1.

Mechanisms by which vitamin D may impact CVD. Adapted from Manson et al, 2012. ${ }^{33}$

PG, prostaglandin; COX-2, cyclooxygenase-2 ; CRP, C-reactive protein ; IL-6, interleukin-6 ; IL-10, interleukin-10 ; TNF-a, tumor necrosis factor-a, MMP-9, matrix metalloproteinase-9; RAAS, renin-angiotension-aldosterone system. 


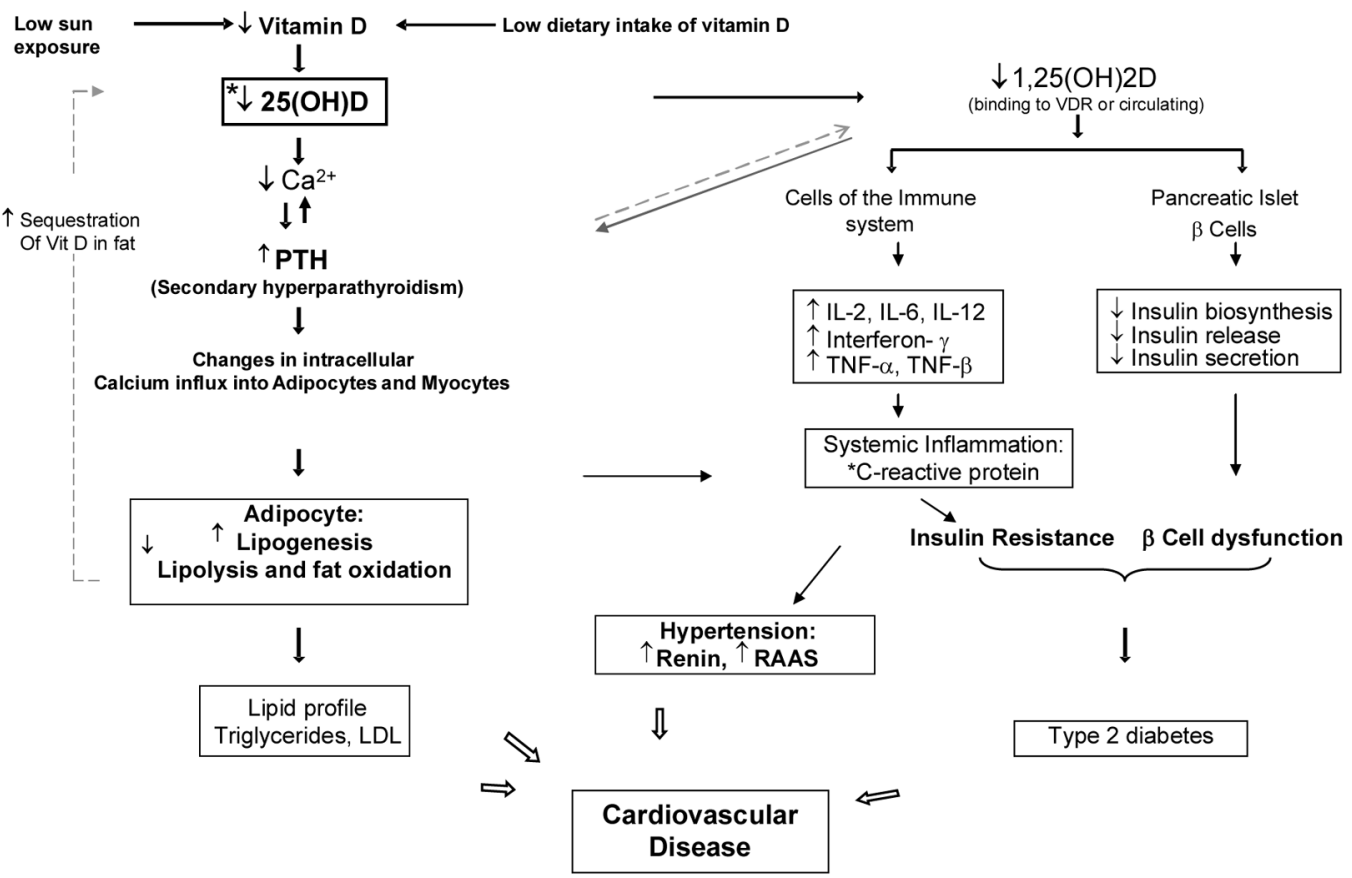

Figure 2.

Hypothesized mechanisms underlying the interrelationships among vitamin D deficiency, cardiovascular disease risk factors such as insulin resistance, hypertension and diabetes. 


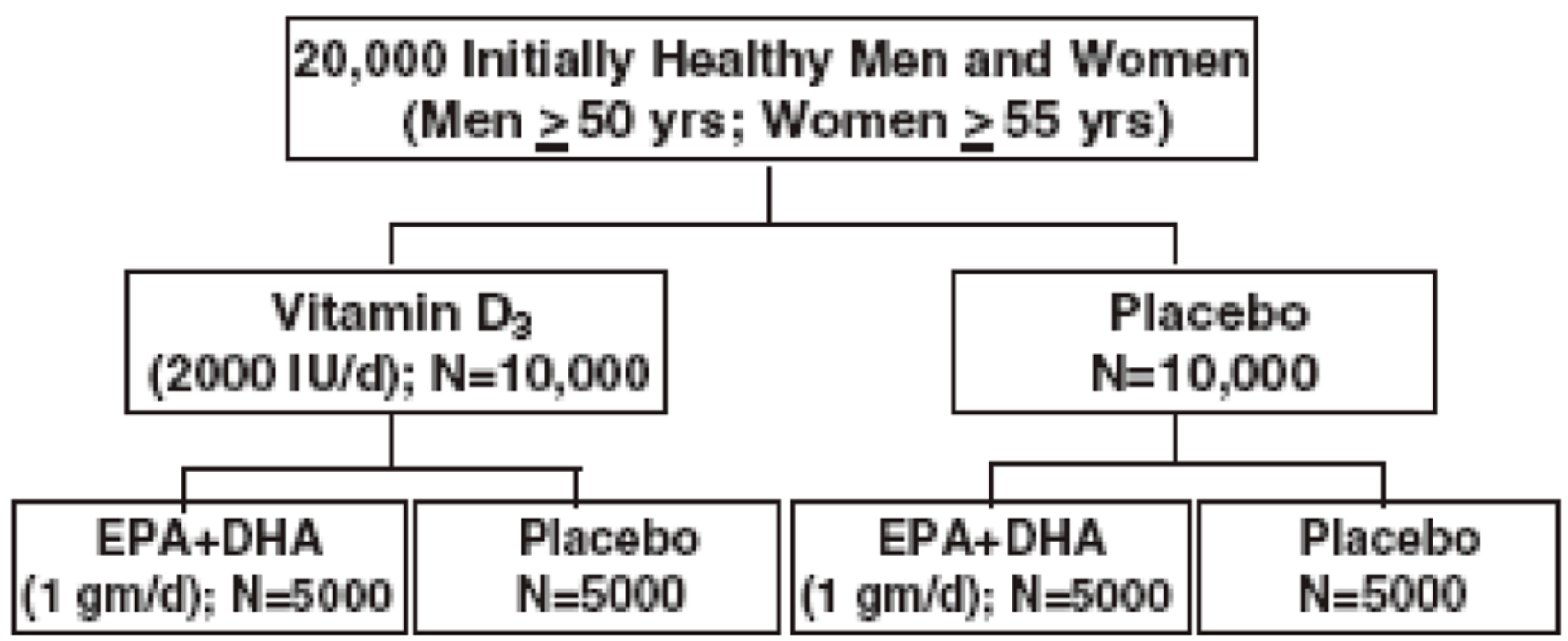

Mean Treatment Period $=5.0$ years

Blood collection in $\sim 16,000$, follow-up bloods in $\sim 6000$

Primary Outcomes: Cancer (total) and CVD (MI, stroke, CVD death)

Fig. 3.

The VITamin D and Omeg $A-3$ Trial (VITAL) design. 